\title{
SUPPLY CHAIN ANALYSIS AND PERFORMANCE ASSESSMENT OF SME FISHERIES CLUSTERS
}

\author{
Anton A Setyawan \\ Universitas Muhammadiyah Surakarta \\ anton.setyawan@ums.ac.id \\ Muzakar Isa \\ Universitas Muhammadiyah Surakarta \\ muzakar.isa@ums.ac.id \\ M Farid Wajdi \\ Universitas Muhammadiyah Surakarta \\ farid.wajdi@ums.ac.id \\ Syamsudin and Sidiq P Nugroho \\ Universitas Muhammadiyah Surakarta \\ sidik_nugroho78@yahoo.com
}

\begin{abstract}
Study of SME in Indonesia related with business networks and performance in these business organizations. In many cases, regional administration in Indonesia develops SME business network in the form of clusters. This study analyzes SME fisheries clusters with supply chain analysis. We also develop performance assessment of SME fisheries cluster by using multivariate model. This study involves 62 SMEs in Sragen, Central Java Indonesia. Those SMEs includes in fisheries cluster in the area. Our findings show that SME fisheries cluster has in-efficient supply chain. This business clusters have problems in profit setting and delivery time which harm their performance. We measure business performance by using business selling, profit rate and asset growth. We found that cost structure, man power and physical production has positive effects to business performance.
\end{abstract}

\section{Keywords}

supply chain management; SME clusters; business performance; business growth

\section{JEL Classification}

Q13; Q18

\section{Introduction}

Supply chain management (SCM) has grown to be an important aspect of business competitiveness (Sohrabpour et al, 2012; Cook et al, 2011). Cook et al (2011) found that SCM has been studied by many researchers to strengthen and develop its validity in numerous industries. Archer (2006) discusses implementation of SCM in different business organizations. One among important issues related SCM implementation in SME (Small and Medium-Sized Enterprises). Characteristic of SME rely on its differences in efficiency, coordination, collaboration and innovation compare with large business organizations (Gracia et al, 2011).

Cluster approach has been widely known as framework of SME in many emerging economies (Karaev et al, 2007). Cluster approach ensure SME optimimized their resource in increasing their profitability. SME has very limited resource, therefore SME should strengthen their business networks. Cluster approach ensure SME share their resources with their partners. Cluster approach and SCM are closely related and match as main business strategy in SME development.

SMEs are dominant business organization in emerging economies, hence it is important to develop appropriate business strategies for them. SCM considered suitable for SME 
business. The key element of SCM is integration of business function, resources and business partners so that their business process allign with overall business objectives (Manuj \& Sahin, 2011). Cluster is a form of business network which appropriate for business development for SME. SME's weakness of resource limitation could be overcome by sharing it with the entire cluster member. Gracia et al (2011) analyze the relationship of SCM with SME competitiveness in agriculture sector in Spain and the important finding is SCM could strengthen business network and process.

The result of all business strategies is increasing business performance. There are different types of business performance in a company. However, SME uses short term operational factor for performance measurement, such as profit, sales, demand and product turnover (Wood, 2007). Long term performance measurement in business organization theoretically is better than operational performance (Brush et al, 1999). SMEs very rarely make assessment of long term business performance such as, asset growth, market share, consumer satisfaction and loyalty. Lamprinopoulou \& Tregear (2011) found that SME business performance measurement is related with SME business network. SME cluster and share resource related with marketing performance of SME (Lamprinopoulou \& Tregear, 2011). Finding in the study is marketing performance in SME rely on short term operational marketing performance, such as selling and revenue. In SME, business performance measurement has various aspects, although it all related with short term operational performance.

This paper analyzes supply chain framework in SME cluster of fisheries. SME of fisheries belongs to agriculture sector. Luna \& Wilson (2015) found that agriculture sector in developing countries has suffered serious problem of oligopoly in their market structure. Oligopoly impacts price setting for farmers in agriculture sector (Vickner \& Davies, 2000). In the condition of oligopoly, there are certain middleman and wholesaler with price setting power (Cakir \& Nolan, 2015). This price mechanism could harm farmers, since they receive little portion of profit. The purpose of this paper is to analyze supply chain of the SME cluster to discover the most important part of supply chain in it. Determining the most important part of supply chain could attain valuable element in the business networks. We also analyze fisheries SME cluster's business performance to explain the role of SCM in the business process.

\section{Supply chain management: conceptual framework}

Soon \& Udin (2011) define supply chain as networks of business in upstream and downstream flows from suppliers to ultimate consumers. From this definition, we could conclude that SCM is a network. It involves different kinds of institution which connected and have a inter-dependency. Manuj \& Sahin (2011) describe flows in SCM is material and information. Information flows in SCM is the distinction of this concept to distributions.

Figure 1 explains SCM with its model of dynamic function. SCM ensures efficiency in the delivery process of product from suppliers to end customer. It also arranges flows of information from customers to manufacturers (Versei et al, 2014). In this process, SCM should integrate with marketing intellegence systems. Marketing intellegence system consists of market research, analysis of costumer segment and customers relationship management. It organizes types of information on market and customers required by other function in the supply chain. 


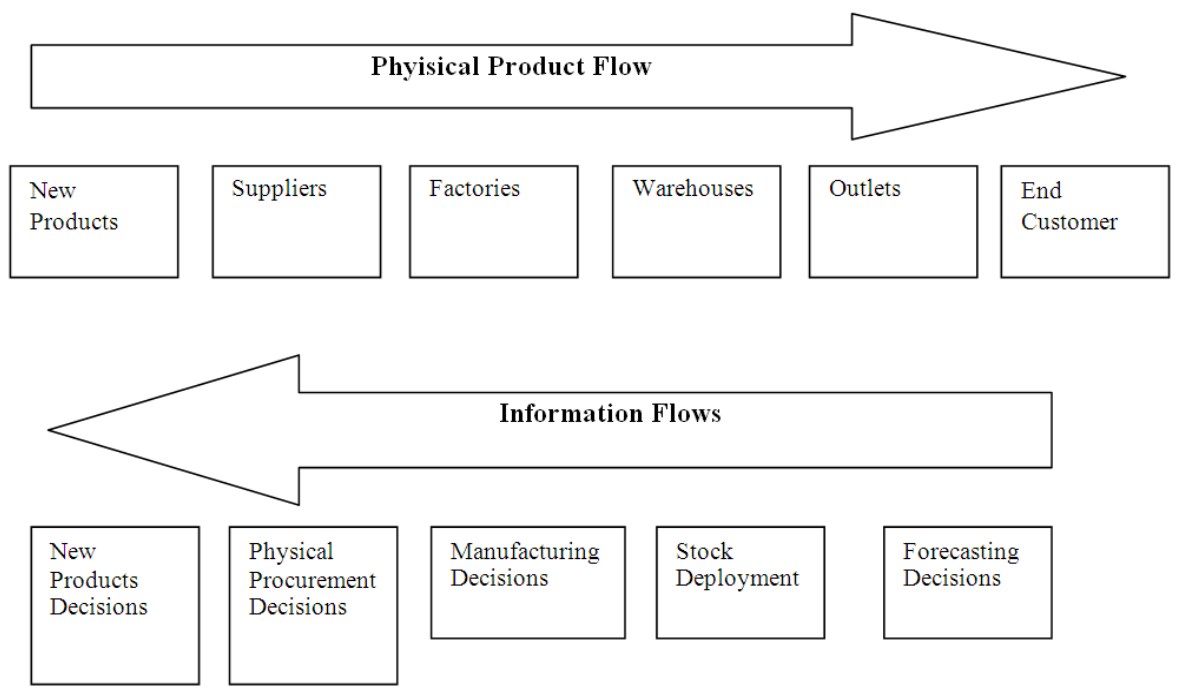

Figure 1 Conceptual Framework of Supply Chain Management

Implementation of SCM in SME is relevant since this business organization should develop business network. Schulze-Ehler et al (2014) found that SCM practice in SME should become attitude in order to make sure companies achieve their efficiency. Kuah (2002) reveals cluster is an appropriate business network for SME. There are several advantages for SME in a cluster; they are specialization for competence, productivity, sharing resource for innovation and cost efficiency (Karaev et al, 2007).

\section{SME business performance}

Business performance is a multidimensional measurement. Cooley (1979) explains that in SME financial performance is acceptable measurement for business performance. On the other hand, Skrinjar et al (2008) develop business performance measurement in $\mathrm{SME}$ in to financial and non-financial performance. The problem is non-financial performance in SME rarely be measured. SMEs do not have competence and resource to measure non-financial performance such as consumer satisfaction, market share, consumer loyalty and market share. Hence, most SMEs assess short term operational performance measurement such as financial and physical productivity performance (Wood, 2007; Wilson \& Smith, 1996). Sels et al (2006) also develop a linking of productivity and performance measurement in SME with human resource management. However, the method still applying operational human resource approach such as labor intensity and wage.

Jermias (2008) investigates factors affecting financial performance in manufacturing industry. Business strategy and competitive intensity of the industry has positive effect on financial performance in manufacturing strategy. Jermias (2008) found that different types of business strategy have different impact to company's business performance. Lamprinopoulou \& Tregear (2011) have different approach in analyzing business performance for SME. They developed business performance based on marketing performance and business network. Lamprinopoulou \& Tregear (2011) suggest SME should improve their business relationship in the clusters to improve their supply chains efficiency and marketing performance.

Wood (2007) develops a model for SME business performance measurement by using logistic regression methods with operational and financial performance. In this 
performance measurement model, the independent variables contain of cost structure, business age, number of employees (man power), pricing method, production and marketing activities. Wilson \& Smith (1996) compare two types of economic sectors, they are agriculture and manufacture and found that financial performance, such as sales and profit growth are relevant as dependent variables in business performance model.

This study developed several hypotheses to develop assessment of SME business performance. Our hypotheses based on models of business performance from Wood (2007), Wilson \& Smith (1996) and Lamprinopoulou \& Tregear (2011).

H1 Cost structure has positive effect on business performance.

H2 Man power has positive effect on business performance.

H3 Physical Productivity has positive effect on business performance.

\section{Research methods}

\section{Research Design}

Research design in this study is quantitative with survey which involves 62 SMEs in fisheries. Our survey has two purposes, first to identify supply chain management of SME fisheries cluster in Sragen Central Java Indonesia, second, to develop business performance assessment model in the SME cluster. We employ multivariate statistic model as the basis of business performance measurement.

\section{Population and Sample}

Population of this study is SME companies in fisheries cluster in Sragen Central Java. This cluster is one among the biggest SME fisheries cluster in Central Java Indonesia. There are more than $130 \mathrm{SME}$ in the cluster. We explore SME fisheries cluster from Sragen Agriculture Agency. We combine two types of sampling methods in this study, they are: simple random sampling and purposive sampling.

In the process of sample determination with sample random sampling the result is 85 SMEs. However, we determine certain characteristics of SME as respondents, they are: SME with more than 2 years business age, experience at least 2 harvest periods and joining Sragen Agriculture Agency Assistance Program.

\section{Variables and Measurement}

Variables in this study related with business performance assessment model. Independent variables in the model are:

1. Cost structure is the amount of total cost in a period of cultivation (in IDR)

2. Man-power is number of SME employees including family member assisting the business (persons).

3. Physical production is the quantity of harvest in a period of cultivation (kilograms).

Dependent variables in the model are:

1. Assets are the amount of SME asset related with the business (IDR).

2. Sales are the amount of sales in every harvest periods (IDR).

3. Profits are the amount of SME profit in every harvest periods (IDR).

\section{Business Performance Model Estimation}

We develop three different models of estimation to measure business performance. We employ logarithm model of regression estimation in order to adjust differences in variation of variables in the model, suggested by Baltagi $(2011 ; 63)$. Those models of estimation are: 
Model Estimation 1: $\log$ Assets $=\alpha_{11}+\beta_{11}$ Man Power $+\beta_{12}$ Log Cost $+\beta_{13}$ Physical Production $+\varepsilon_{11}$

Model Estimation 2: Log Sales $=\alpha_{21}+\beta_{21}$ Man Power $+\beta_{22}$ Log Cost $+\beta_{23}$ Physical Production $+\varepsilon_{21}$

Model Estimation 3: Log Profit $=\alpha_{31}+\beta_{31}$ Man Power $+\beta_{32}$ Log Cost $+\beta_{33}$ Physical Production $+\varepsilon_{31}$

\section{Results and discussions}

\section{SME Clusters Fisheries in Sragen Central Java}

SME clusters in Sragen consists of 130 groups of fish farmers. Every group has at least 10-25 members fish farmers. There are only 75 percent of SMEs in this clusters active in running their business. From those 75 SMEs, there are only 65 groups of fish farmers meet the requirement as our respondents. They have varieties of fish commodities. Commonly, in SME cluster of fisheries in Sragen raising three kinds of freshwater fish, they are cat fish, parrot fish and goramy fish. Table 1 shows important information about those 65 SMEs fisheries clusters.

Table 1 Key Indicators of SME fisheries cluster in Sragen

\begin{tabular}{lc}
\hline \multicolumn{1}{c}{ Key Indicators } & Average Value \\
\hline Number of Employee/Man Power & 14 persons \\
Production Cost & $72,458,034.48$ IDR \\
Sales & $235,116,491.228 \mathrm{IDR}$ \\
Assets & $263,536,571.400 \mathrm{IDR}$ \\
Gross Profit & $135,000,145.500 \mathrm{IDR}$ \\
Productivity & $9,703.760 \mathrm{~kg}$ \\
\hline
\end{tabular}

Based on the key indicators of SME fisheries cluster in Sragen, we found that this business is profitable with level of margin more than $70 \%$ gross profit. However, there are certain disparities among fish farmers. Our descriptive statistics analysis shows that most of fish farmers have only 25,000,000 IDR on sales and 2,900,000 IDR on profit.

\section{Supply Chains of SME Fisheries Cluster in Sragen}

Our survey identifies 4 types of business in SME fisheries cluster. They are:

1. Suppliers of fish feed and vitamins.

2. Fish breeder farmers

3. Fish rearing farmers.

4. Broker and wholesaler fish farmers.

Suppliers of fish feed and vitamins are important for SME fisheries cluster since most farmers depend on the quality and price of fish feed to achieve optimum productivity. It's often in the survey fish farmers make an assessment of profit based on quantity of fish feed in the periods of cultivation. Vitamins are not considered important because most of fish farmers in SME fisheries cluster cultivate catfish and this type of fish is pest resistant.

Fish breeder farmers are not dominant in the clusters. There are only few of them. However, they play important role in the supply chain since the quality of fish harvest depend on the fish fry. Most of fish farmers in the cluster have competence to be a breeder. The demand of fish fry is also fulfilled by several suppliers from Jogjakarta and East Java. 
Fish rearing farmers are dominant in the SME fisheries cluster. In the cluster, fish rearing farmers usually join group to share resource such as fish fry, fish feed and vitamins. There is a leader in every group and the leader is farmer with highest capital or else holding information about market condition. Every group contains of 10 to 15 farmers and they play an important role in maintain the productivity of SME fisheries clusters. On average SME fisheries produce 9,703 kilogram of fishes every harvest periods or 60 to 70 days. Most of groups of fish fearing farmers have the ability to produce 1500 kilograms of fishes in 60 or 70 days with catfish as the dominant commodity. Failure of harvest in fish fearing will cause lack of fish supply in the market, and the demand should be fulfilled from East Java.

Broker and wholesaler fish farmers usually a leader in a group of fish fearing farmers. They have direct access to the market, suppliers and financial institution. They also possess power to determine price of fish commodities in local market. However, they play vital role in sustaining the production level of SME fisheries cluster. They provide loan for member of fish fearing farmers in the form of fish fry and fish feed. Broker and wholesaler fish farmers usually have a good relationship with local government so that they become an entry point for government agency to organize SMEs assistance program. Figure 2 shows relationship among SME in Sragen Fisheries cluster.

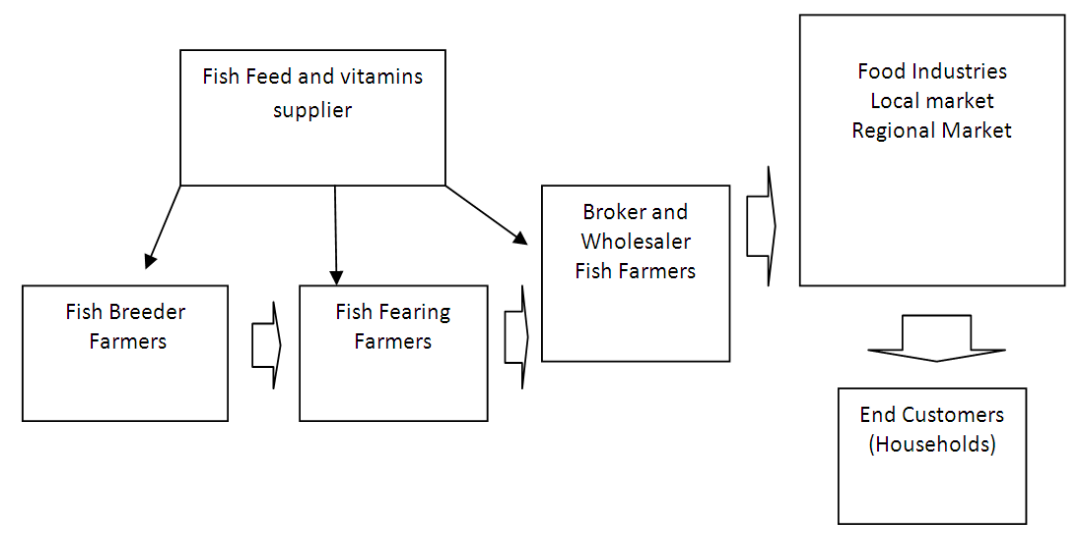

Figure 2 SMEs Fisheries Cluster in Sragen

\section{Business Performance Assessment}

Table 2 shows the result of regression analysis with logarithm model.

Table 2 Regression Analysis Results

\begin{tabular}{|c|c|c|c|}
\hline $\begin{array}{c}\text { Independent } \\
\text { variables and } \\
\text { Goodnes of Fit }\end{array}$ & $\begin{array}{c}\text { Model Estimation } \\
1 \\
\text { (Dependent } \\
\text { Variable: Log } \\
\text { Assets) }\end{array}$ & $\begin{array}{c}\text { Model Estimation } \\
2 \\
\text { (Dependent } \\
\text { Variable: Log } \\
\text { Sales) } \\
\end{array}$ & $\begin{array}{c}\text { Model Estimation } \\
3 \text { (Dependent } \\
\text { Variable: Log } \\
\text { Profit) }\end{array}$ \\
\hline Intercept & $3.720 * *$ & $2.863 * *$ & $2.832 * *$ \\
\hline Man Power & -0.000079 & 0.000256 & $0.011 * *$ \\
\hline Log Cost & $0.611 * *$ & $0.622 * *$ & $0.497 * *$ \\
\hline Log Production & -0.0000073 & $0.0000083 * *$ & $0.221 * *$ \\
\hline $\mathrm{R}^{2}$ & 0.312 & 0.547 & 0.467 \\
\hline F Stat & $7.851 * *$ & $20.969 * *$ & $15.970 * *$ \\
\hline
\end{tabular}

Notes: ** significant at 0.05 level of confidence 
Our models of estimation show different results. Model estimation 1, with log assets as dependent variable, resulted just log cost as independent variable which statistically significant has positive effects to the dependent variable. In the model estimation $2, \log$ production and log cost have positive effect on log sales. However, log production has very small coefficient so that it can be ignored. Model estimation 3 has the best result. Man power, $\log$ cost and $\log$ physical production has positive effect on log profit. $\mathrm{F}$ statistic in all models is statistically significant, whereas the level of $\mathrm{R}^{2}$ is low, so that the goodness of fit of the model is acceptable.

Models of estimation in this study gives important measurement about SME business information. The result of the model confirms Wood (2007) and Wilson \& Smith (1996) findings that short term operation performance in SMEs could explain their performance better. SME fisheries cluster in Sragen have several similar performance characteristics with most SME cluster in developing countries. Cost structure is dominant in explaining business performance. Srimuk \& Choibamroong (2015) also found that cost is an important factor in determining investment strategy in SMEs. It can be concluded that SMEs could achieve high business performance by optimizing cost efficiency.

Man-power in SMEs is partially important. Our model of estimation shows that man power has positive effect on profit and sales but irrelevant to increase SME assets. This finding is similar with Sels et al (2006) and Cooley (1979) conclusions that human resources play vital role to increase business performance. However, man power in SMEs is also related with employee from family members and low wages. It explains the result of our model that regression coefficient is very small considering the fact that labor in SME fisheries cluster in Sragen are underpaid.

Physical production in this study closely related with profit and does not effect on assets. It means that farmers in this cluster use their profit to consumption or investment instead of growing their assets. There are two reasons for this phenomenon. First, most of farmers in the cluster received small portion of profit. Our data on profit shows that the mode of profit is only IDR 2,900,000 for every period of harvest. With only small portion of profit, fish farmers are commonly having other business and makes them part time fish farmers. Second, fish farmers use their portion of profit for investment for the next period of cultivation, for example; buying fish fry and feed fish or repair the fish ponds. Lofving et al (2014) and Srimuk \& Choibamroong (2015) suggests that SME should improve their investment strategy by considering long term impact of their business. This includes make an assessment of return on investment, return on assets and business risks in their business.

Our model of estimations could be guidance to develop SME business performance measurement. The models show fish farmers business and investment behavior. However, the model of SME business performance measurement gives only short-term operation information about the business. The models could not make a long-term prediction since SME do not have long term data due to weakness in business data storage. Most of SME in the cluster do not compile annual financial, business planning and evaluation report.

\section{Conclusions and implications}

Supply chains analysis of SME fisheries cluster in Sragen shows the importance of business network. SME in the cluster could improve their business by sharing resource with their partners. Strategic partnership in SME has develop among feed fish and vitamins supplier, fish breeder farmers, fish fearing farmer and broker and wholesaler fish farmers. Broker and wholesaler fish farmers become leader in the business network due to their possession of market access, cultivation technology and financial resource. 
They also become a price setter but always considering the interest of smaller farmers. There is a mutual relationship in the supply chains of SME fisheries cluster in Sragen. SME fisheries cluster in Sragen have a common characteristic in business performance with other SME cluster in developing countries. We develop model of estimation to measure business performance which involves short term operation performance such as man power, cost structure and physical production as independent variables. Our operational variables of business performance are assets, sales and profits. In the models, man power, cost structure and physical production have positive effects to business performance. Man-power or human resource have small regression coefficient this is due to the fact that human resource has long term effect to business performance, while dependent variables in the model are short term measurement of performance. Theoretical implications of this study are, first, this study contributes to the theoretical and conceptual development of supply chain in SME cluster in developing countries. Karaev et al (2007) identify such study is very few. The importance contribution of this study related with the emerging of business networking groups in the cluster. There is a leader in every group who plays vital role to the business performance to the group. In the future, researcher should consider measuring the supply chains efficiency. Second, business performance measurement in this study contributes to recent issue in SME business performance on the operational variables (Wood, 2007; Sels et al, 2006). This study employs short term operational business performance which shows the behavior of SME business in their business decisions. In the future, researchers should focus on strategic and long-term performance of SME business.

Managerial implications of this study are, first, SME managers and owners should develop their business networks. SME cluster is the form of business network which give several advantages for their business. They are: resource sharing of technology, financial aspects and markets. SME cluster also give advantage in achieving optimum productivity. Second, SME should develop their business performance and considering long term existence of their business. SME managers and owner in fisheries cluster have to compile their business and investment plan for the future.

This study has several limitations; first, supply chain analysis in SME fisheries cluster could not identify suppliers or buyer outside Sragen. The clusters related with suppliers from different region such as fish fry suppliers from Jogjakarta and Purwodadi. These suppliers determine the quality of fish harvest. We could not get more information about these suppliers. We also get limited information about buyer from industry outside SME fisheries cluster in Sragen. These limitations are the reason this study could not explain price determination and supply of fish in the local market. Second, our models of business performance assessment could not predict long term condition of SME fisheries cluster due to limited information about non-financial performance, such as consumer's loyalty and satisfaction, market share and competition analysis.

\section{References}

Baltagi, B.H. (2011), Econometrics, Fifth Edition, New York, Springer.

Brush, T.H., Bromiley, P., Hendrick, M. (1999), The Relative Influence Of Industry And Corporation On Business Segment Performance: An Alternative Estimate, Strategic Management Journal, 20, 519-547.

Çakır, M., Nolan, J. (2015), Revisiting Concentration in Food and Agricultural Suly Chains: The Welfare Implications of Market Power in a Complementary Input Sector, Journal of Agricultural and Resource Economics, 402, 203-219.

Cook, L.S., Heiser, D.R., Sengupta, K. (2011), The Moderating Effect Of Suly Chain Role On The Relationship Between Suly Chain Practices And Performance: An Empirical Analysis, International Journal Of Physical Distribution \& Logistics Management, 41(2), 104-134. 
Cooley, P.L. (1979), Managerial Pay and Financial Performance of Small Business, Journal Of Business Research, 13(3), 267-276.

Gracia, A., Magistris, T.D., Albisu, L.M. (2011), Supply Chain Relationships and SME Firms' Competitiveness in the Spanish Pig-to-Cured Ham Chain, Journal of International Food \& Agribusiness Marketing, 23,192-210.

Jermias, J. (2008), The Relative Influence of Competitive Intensity Business Strategy On The Relationship Between Financial Leverage And Performance, The British Accounting Review, 40, 71-86.

Karaev, A., Koh, S.C.L., Szamosi, L.T. (2007), The Cluster Aroach And SME Competitiveness: A Review, Journal Of Manufacturing Technology Management, 18(7), 818-835.

Kuah, A.T.H. (2002), Cluster Theory and Practice: Advantages for the Small Business Locating in a Vibrant Cluster, Journal of Research in Marketing and Entrepreneurship, 4(3), 206-228.

Lamprinopoulou , C., Tregear, A. (2011), Inter-firm Relations In SME Clusters And The Link To Marketing Performance, Journal of Business \& Industrial Marketing, 26(6), 421-429.

Lofving, M., Safsten, K., Winroth, M. (2014), Manufacturing Strategy Frameworks Suitable For SMEs, Journal of Manufacturing Technology Management, 25 (1), 7-26.

Luna, F., Wilson, P.N. (2015), An Economic Exploration of Smallholder Value Chains: Coffee Transactions in Chiapas, Mexico, International Food and Agribusiness Management Review, 18(3), 85-106.

Manuj, I., Sahin, F. (2011), A Model Of Supply Chain And Supply Chain DecisionMaking Complexity, International Journal Of Physical Distribution \& Logistics Management, 41(5), 511-549.

Schulze-Ehlers, B., Steffen, N., Busch, G., Spiller, A. (2014), Supply Chain Orientation In SMEs as An Attitudinal Construct Conceptual Considerations And Empirical Alication To The Dairy Sector, Supply Chain Management: An International Journal, 19(4), 395-412.

Sels, L., Winne, S.D., Delmotte, J., Maes, J., Faems, D., Forrier, A. (2006), Linking HRM and Small Business Performance: An Examination of the Impact of HRM Intensity on the Productivity and Financial Performance of Small Businesses, Small Business Economics, 26, 83-101.

Skrinjar, R., Bosilj-Vuksic, V., Indihar-Stemberger, M. (2008), The Impact Of Business Process Orientation On financial and Non-financial Performance, Business Process Management Journal, 14(5), 738-754.

Sohrabpour, V., Hellstrom, D., Jahre, M. (2012), Packaging In Developing Countries: Identifying Supply Chain Needs, Journal Of Humanitarian Logistics And Suly Chain Management, 2(2), 183-205.

Soon, Q.H., Udin, Z.M. (2011), Supply Chain Management From The Perspective Of Value Chain Flexibility: An Exploratory Study, Journal Of Manufacturing Technology Management, 22(4), 506-526.

Srimuk, N., Choibamroong, T. (2015), Business Investment Strategy of SME Restaurants, Research Journal of Business Management, 9(3), 457-469.

Varsei, M., Soosay, C., Fahimnia, B., Sarkis, J. (2014), Framing Sustainability Performance Of Suly Chains With Multidimensional Indicators, Supply Chain Management: An International Journal, 19(3), 242-257.

Vickner, S.S., Davies, S.P. (2000), Estimating Strategic Price Response in a ProductDifferentiated Oligopoly: The Case of a Domestic Canned Fruit Industry, Agribusiness, 16(2), 125-140. 
Wilson, T.L., Smith, F.F. (1996), Business Services 1982-1992 Growth, Industry Characteristics, Financial Performance, Industrial Marketing Management, 25, 163-171.

Wood, E.H. (2006), The Internal Predictors Of Business Performance In Small firms A Logistic Regression Analysis, Journal of Small Business and Enterprise Development, 13(3), 441-453. 